\title{
Study on the State Grid Operational Diagnosis Index System
}

\author{
Jijun Wang1, Jing Tan², Lisha Gao', Hui Zhang ${ }^{3}$ \\ ${ }^{1}$ State Grid Jiangsu Electric Power Company, Nanjing, China \\ ${ }_{2}^{2}$ Jiangsu Electric Power Information Technology Co. Ltd., Nanjing, China \\ ${ }^{3}$ Beijing China Power Information Technology Co., Ltd, Beijing, China \\ Email: zhangcaihb1992@163.com
}

Received 30 March 2016; accepted 18 July 2016; published 25 July 2016

\begin{abstract}
This research analyzes the strategy objectives in the financial level, customer level, the internal level, learning and growth level with the method of the strategy map, and then sets up the targets on each strategic objectives. At last, this paper analyzes indicators to measure these targets, and establish the enterprise operation index system aiming to provide a new way of thinking and methods for evaluating the operation of Power Grid Corp.
\end{abstract}

\section{Keywords}

\section{Operation Diagnosis, Index System, Strategy Map}

\section{Introduction}

In recent years, the State Grid aims to accelerate the construction as a modern enterprise, and create a "worldclass power grid, international first-class enterprise". To reform as a driving force, it's a target to improve the modern enterprise system, complete the restructuring of the grid enterprise business, assets, institutions and personnel, strengthen enterprise management, transform the management mechanism, and initially establish a modern enterprise system. It's important to accelerate structural adjustment, optimize the allocation of resources, realize asset to maintain value rise, and finally realize the goal of constructing the national power grid enterprise to a modern large-scale enterprise.

In this context, the scientific enterprise diagnosis is very necessary. This paper constructs the enterprise operation diagnosis index system based on the strategic map analysis method. The system, according to the strategic map, fully reflects the business operations in financial level, customer level, internal level, and learning and growth level.

We focused on the important aspects during the indicator selection process. The system covers the major aspects of the business operations and fully reflects the current state power grid development strategic planning, so that the enterprise can find some potential questions through the analysis of the data of index system and achieve a stable development. 


\section{Research Method}

This paper adopts the method of strategy map. Strategy map theory was formally proposed by Robert Kaplan and David Norton in 2004 in their co-authored book, "strategy map-converting in tangible assets into tangible outcomes", which is an important part of the famous theoretical system, the balanced score card. The strategy map completely interprets the logic of the Balanced Scorecard theory: it is a must to be able to measure strategy before managing strategy, and it is a must to be able to describe strategy before measuring strategy.

As a strategy performance management and evaluation tool, the strategy map mainly measures the corporate from financial level, customer level, internal process level, and learning and innovation level. The core idea is to show the strategic trajectory through analyzing the interaction between the four indicators.

\section{Analysis Process}

\subsection{Determined All Levels of the Power Grid Strategic Direction According to the Strategy Map Analysis Method}

According to the analysis above, the strategy map mainly measures corporate from financial level, customer level, internal process level, and learning and innovation level. Therefore, this study, combining with the development strategy and the actual situation of the national grid, firstly determines the strategic objectives of the four levels.

The total strategic goal in the financial level for the enterprise is value growth. At the customer level, four main bodies related to China State Grid Corp are the state and society, users, power plants, and the international market. Therefore, at this level, State Grid's strategy is to coordinate the relationship with the four main bodies. At the internal level, the strategy is development, construction and investment efficiency, operation, overhaul, and quality of service. At the learning and growth level, the strategy is human capital, information capital, and material management ability.

\subsection{Determining the Target Level According to the Strategic Direction}

At the financial level, we determine the five specific targets: cost, level of profitability, solvency, operation ability, and development ability.

At the state and society level, the targets are environment protection, resource conservation and social contribution. At the user level, as the State Grid is an electric energy service provider, the specific targets are reliability, economy, and quality.

At the power plant level, the power generation enterprises pay close attention to the cooperation with the national grid and the economic benefits from the cooperation, so the specific targets are environmental protection and power plant economy. At the international market level, as the national grid positively develops national business in recent years, therefore, the specific targets are the development of international institutions and the development of overseas business.

At the internal level and the learning and growth level, we set goals according to the company strategic direction the same way as the levels above, which will be discussed in the following sections.

\subsection{Determining Index System According to the Corresponding Target Index}

Based on the basic theory of strategic map, we analyze strategic objectives and specific targets in all aspects of the national grid, and operation diagnosis index system is formulated referring to these goals and national grid existing index database.

\section{Results and Discussion}

According to strategy map theory, we can get the strategy map of State Grid. As shown below, Figure 1 shows the goals and specific targets of national grid in the financial level, customer level, internal level, learning and development level. Specific indicators based on these targets are further provided to measure these goals.

\subsection{Financial Level}

All the financial risk management fields must be incorporated into the scope of the study when we determine the 


\section{Strategy Map of The State Grid}

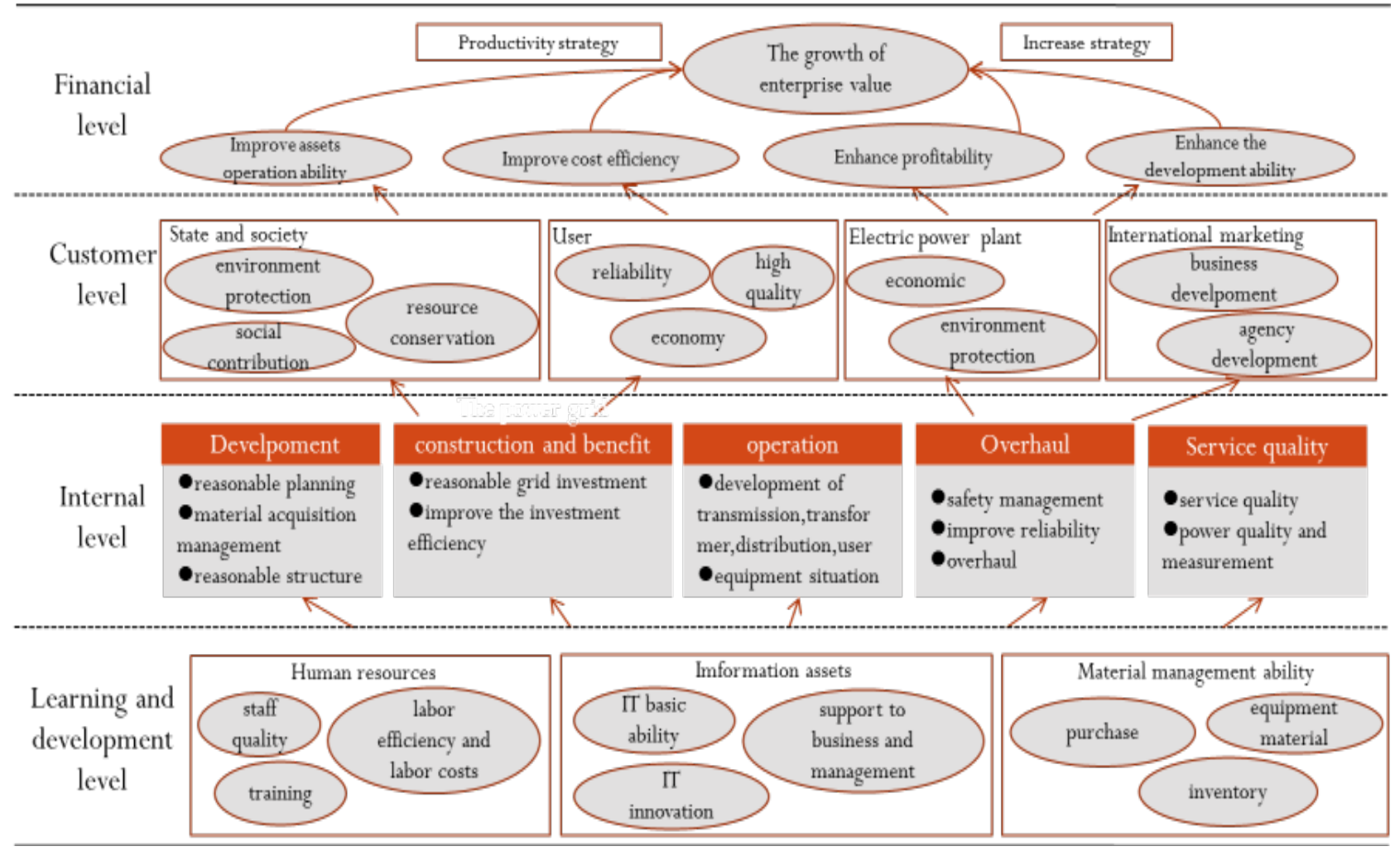

Figure 1. Strategy map of the state grid.

enterprise financial risk indicators, so this study analyzes the risks from five aspects, namely cost, profit ability, debt paying ability, operating ability, and development ability. The analysis at the cost level shows if cost control is reasonable in the process of enterprise operation. Profitability analysis shows the questions of business links. Solvency analysis shows the enterprise's ability to continue as a going concern and its risks. Operational capacity study shows the assets operation ability. Developmentability study shows the development trend of the enterprise, and judges whether there are risks in its operating and financial decisions. These four aspects including static indicators and dynamic indicators, can reflect the financial position, operating results, and judge the existence of enterprise financial crisis (Table 1).

\subsection{Customer Level}

At the customer level, it mainly analyzes the four main bodies which are closely connected with the National Grid: the state and society, the sale of electricity purchase terminal, terminal and the international market.

\subsubsection{State and Society}

With the national energy development strategy as the guidance, the targets are to save energy and reduce emissions of harmful gases (Table 2).

\subsubsection{User}

As the electric power service provider, the national grid should promote the sale of electricity, power efficiency and user satisfaction, improve the user management and service standard system. It's also important to improve power supply reliability [1], quality and economy [2], and improve the quality of electric energy, which means reducing the average outage time of the power users, reducing the user's loss caused by power outages and electric energy quality problems, and enhancing the stability [3] (Table 3). 
Table 1. Specific indicators of financial level.

\begin{tabular}{ll}
\hline Cost level & Cost Profit Ratio \\
& A unit of electricity transmission and distribution cost transmission and \\
distribution cost transmission and distribution cost transmission and distribution cost & Per million of power grid assets operation and maintenance costs \\
& Operating Profit Margin \\
Profitability & Rate of Return on Common Stockholders' Equity \\
& Return on Total Assets \\
Financial & Quick Ratio \\
level & Debt to Assets Ratio \\
& Receivables Turnover Ratio \\
& Current Assets Turnover \\
& Total Assets Turnover \\
& Operating Profit Growth Rate \\
& Main Business Revenue Growth Rate \\
& The rate of remain and increasing value of the state-owned assets \\
\hline
\end{tabular}

Table 2. Specific indicators of state and society level.

\begin{tabular}{ll}
\hline Generation rights trade coal saving \\
& Generation right transaction reduction $\mathrm{SO}_{2}$ \\
& Generation right transaction reduction $\mathrm{CO}_{2}$ \\
& Energy saving distribution transformer ratio \\
& $*$ The utilization rate of land resources \\
& *Elasticity Ratio of Electricity Consumption \\
& $*$ energy consumption per GDP \\
& $*$ the ability of promoting employment \\
& $*$ The pulling effect of grid on related industries \\
\hline
\end{tabular}

Table 3. Specific indicators of user level.

\begin{tabular}{ll}
\hline Reliability & *Average customer interruption times (million users) \\
& Rural users average outage time \\
& City users average outage time \\
& The qualified rate of user voltage \\
& The qualified rate of user frequency \\
& Rural users average electricity outage time \\
& City user average electricity outage time \\
& $*$ The average voltage drop times \\
& $*$ Average instantaneous interruption times \\
& The average load rate \\
& $*$ The average user outage loss (reduced income from outage) \\
\hline
\end{tabular}




\subsubsection{Electric Power Plant}

Since several competitors formed at the generation side, all power enterprises became independent economic entity, which pursuit maximizing its benefit. Therefore, power companies pay more attention to the cooperation with the national grid and its economic benefit (Table 4).

\subsubsection{International Marketing}

In recent years, the State Grid has been working in constructing "a world-class power grid, an international first-class enterprise”, and its business is actively expanding into the international market. Through international distribution, its ability of international company business management has improved significantly. The development of the international market also has a certain role in promoting the development of power grid enterprise. Therefore, it's necessary to pay attention to exploration and development of the international market in the index system. The specific indicators consist of overseas business income, interests and development of overseas institutions (Table 5).

\subsection{Internal Level}

According to the company's strategy, it's necessary to focus on the human resources, financial, material intensive management, the planning, construction, operation, overhaul, and marketing system.

At the internal level, mainly based on the strategic requirements, we select the relevant diagnostic indicators in the five aspects of power grid development, power grid construction and investment efficiency, power grid operation, maintenance and customer service.

\subsubsection{The Development of Power Grid}

We pay attention to accuracy rate of planning project, material procurement, the situation of grid lines from the aspect of the development of State Grid (Table 6).

Table 4. Specific indicators of power plant level.

\begin{tabular}{ll}
\hline & Unit coal consumption \\
& The new energy power generation capacity \\
& The purchase (sale) contract execution rate \\
& The rate of timely reply inquiries \\
Power plant & The Internet power timely settlement rate \\
& $*$ The utilization rate of power generation equipment \\
& $*$ Average utilization hours of generating equipment \\
\hline
\end{tabular}

Table 5. Specific indicators of the international market financial level.

\begin{tabular}{cl}
\hline & Overseas contract amount \\
& Overseas business income \\
The international market & The total profit of overseas business \\
(for group) & Total amount of overseas assets \\
& The number of overseas institutions \\
& $*$ The proportion of the operating income in the total income \\
\hline
\end{tabular}

Table 6. Specific indicators of the development level.

\begin{tabular}{ll}
\hline & Project planning accuracy rate \\
The development of power grid & The procurement standard execution rate \\
& Capacity-load ratio \\
& The passing rate of power grid N-1 \\
& $*$ The utilization rate of power equipment \\
\hline
\end{tabular}




\subsubsection{Construction and Investment Efficiency}

As power grid construction is the foundation of development, the investment and efficiency of equipment are important factors (Table 7).

\subsubsection{Operation}

The diagnosis of power grid operation is mainly from the evaluation of power transmission, substation, power distribution and power users, and at the same time, we evaluate the operation of the power grid equipment.

a) Transmission link

The goal of building a smart grid transmission side is to enhance the transmission capacity of transmission lines, reduce transmission cost, strengthen the line running state considerable and controllability, and realize state assessment, fault diagnosis, maintenance and risk early warning. It mainly consists of the key technology of UHV transmission, flexible HVDC transmission line, transmission line condition monitoring and intelligent inspection (Table 8).

b) Transformer link

The development of the transformer side focuses on intelligent substation, and its main goal is to provide reference for smart grid scheduling and equipment operation management optimization and decision through the construction of Smart Substation and other intelligent device (Table 9).

c) Dispatching link

At the dispatching link, the key problem to solve is safety and stable operation of large power grid; energy saving, emission reduction and resources allocation optimization, and grid integration operation coordination control.

Based on the distributed integration platform, it's important to realize homogenization scheduling management, enhance grid scheduling control ability and optimize the ability of the resource allocation, decision-making, regulation and control, grid security, stability, economic operation, high quality guarantee. The construction of distribution network, distribution automation, the popularization of electric vehicles and distributed energy access are also important concerns. The targets are to building the efficient, flexible and reasonable distribution network, achieve centralized/decentralized storage compatible access, unified control device and distributed power supply, and complete the construction of practical distribution automation system (Table 10).

Table 7. Specific indicators of the construction and investment benefit level.

The scale of under-construction project

*The unit power supply load increase investment

*The increase electricity per power investment

Construction and investment benefit

Asset formation rate

Investment income ratio

The number of equipment and materials’ defects for new production

Table 8. Specific indicators of the transmission link.

The scale of UHV transmission line

The scale of flexible transmission device application

Transmission link

The proportion of new transmission technology application

Transmission line condition monitoring rate

Intelligent inspection rate of transmission line

Table 9. Specific indicators of the transformer link.

Transformer link
The proportion of Smart Substation

Intelligent substation capacity ratio

Intelligent substation equipment rate 
Table 10. Specific indicators of the dispatching link.

\begin{tabular}{ll}
\hline Dispatching and operation & The daily load forecasting qualified rate \\
& The proportion of $220 \mathrm{kV}$ and above unattended substation \\
& At or above the provincial level monitoring information accuracy \\
& The actual maximum power delivery of cross line \\
& Adjustable capacity \\
& Insulated overhead line rate of city distribution network \\
& Distribution automation terminal coverage rate \\
Distribution link & Distributed power grid connection capacity \\
& The construction scale of Micro-grid system \\
\hline
\end{tabular}

d) User link

The main task of user side is the construction of the electricity information collection system, the construction of two-way interaction between the user and the system of power grid, and finally to enhance the efficiency of user electric energy utilization and operation. In addition, the development of the smart grid user side focuses on the promotion of electric vehicles and the construction related to charge and discharge facilities (Table 11).

e) Equipment situation

The condition of the equipment is very important during the operation process. Therefore, health and economy of equipment are two important aspects to diagnose (Table 12).

\subsubsection{Overhaul}

Network security is an important aspect of power grid construction. Therefore, maintenance is an essential link. Three aspects of grid maintenance focus on safety management, reliability, and maintenance condition. Maintenance of accidents and the situation of power grid are necessary (Table 13).

\subsubsection{Customer Service}

The evaluation of customer service is mainly to measure service quality and power quality (Table 14).

\subsection{Learning and Development}

\subsubsection{Human Resources}

In the diagnosis of human resources, we need to analyze the team quality, and the analysis consist of the proportion of employees with different levels of education and titles, employee work efficiency and training development [4] (Table 15).

\subsubsection{IT Capability Maturity}

The enterprise IT capability maturity consists of four dimensions, which are basic ability, ability of supporting business, ability of supporting management, and ability of IT learning and innovation [5] (Table 16).

\subsubsection{Material}

The diagnosis of the enterprise supplies focuses on the power grid investment and construction, inventory, and procurement bidding (Table 17).

Based on the strategy map method, this study analyzes the strategic goals of the national grid in four different levels of and the specific targets of strategic objectives. Combined with the existing internal index database, we established an enterprise diagnosis index system and provided a new method for diagnosis of power grid operation.

According to the analysis, we identify 4 categories, 17 small classes, a total of 121 evaluation indexes, and the results provide an effective basis of improving and enhancing the business. The "*” label is recorded on the indexes which are not in the existing index database, and the enterprise can add these indicators into the base in 
Table 11. Specific indicators of the user side.

\begin{tabular}{ll}
\hline User link & Smart meter penetration rate \\
The scale of electricity information collection system & The scale of electric vehicle charging facilities \\
Electric vehicle charging load & The scale of intelligent electric cell/building \\
\hline
\end{tabular}

Table 12. Specific indicators of the equipment situation.

\begin{tabular}{ll}
\hline Health level & The proportion of equipment condition evaluation \\
& The proportion of transmission line state evaluation \\
Economy & Power equipment operation and maintenance costs \\
& The average load loss rate \\
\hline
\end{tabular}

Table 13. Specific indicators of overhaul.

\begin{tabular}{|c|c|c|}
\hline \multirow[t]{8}{*}{$\begin{array}{l}\text { Security } \\
\text { management }\end{array}$} & Personnel safety accident & The number of Personal events over 4 level \\
\hline & & The total number of personal deathevents \\
\hline & & The total number of personal injury accident \\
\hline & Power Grid Accident & Responsible serious accident in power grid \\
\hline & & Cable misoperation of over $10 \mathrm{kV}$ accident \\
\hline & & Substation accident rate \\
\hline & & Transmission accident rate \\
\hline & Equipment accident & Equipment accident rate \\
\hline \multirow[t]{3}{*}{ Reliability } & Power equipment failure rate & \\
\hline & Large scale blackout times & \\
\hline & The average outage time & \\
\hline \multirow{3}{*}{$\begin{array}{l}\text { Grid } \\
\text { maintenance }\end{array}$} & Transport inspection performance & Timely elimination rate of serious defects \\
\hline & State maintenance & The coverage rate of equipment maintenance \\
\hline & Heavy Repair and Technical Improvement & The completion rate of technical transformation investment plan \\
\hline \multirow[t]{4}{*}{ Service quality } & \multicolumn{2}{|c|}{ Average electrical connection time of high-press customer business expanding } \\
\hline & \multicolumn{2}{|l|}{ The average duration of power failure } \\
\hline & \multicolumn{2}{|l|}{ 95598service satisfaction rate } \\
\hline & \multicolumn{2}{|l|}{ Customer satisfaction rate } \\
\hline \multirow{3}{*}{$\begin{array}{l}\text { Power quality } \\
\text { and measurement }\end{array}$} & \multicolumn{2}{|c|}{ The pass rate of electric energy metering device configuration } \\
\hline & \multicolumn{2}{|c|}{ The qualified rate of comprehensive voltage } \\
\hline & \multicolumn{2}{|c|}{ Power supply reliability rate (The average user outage time, The average user outage times) } \\
\hline
\end{tabular}


Table 15. Specific indicators of human resources.

\begin{tabular}{lll}
\hline & Staff quality & $\begin{array}{l}\text { The equivalent density of talents } \\
\text { (the proportion of different academic background and titles) } \\
\text { Human resources }\end{array}$ \\
\cline { 2 - 2 } & Labor efficiency and labor costs & $\begin{array}{l}\text { Overall labor productivity } \\
\text { (The increased production value/The average number of staff) }\end{array}$ \\
Training development & The per capita funding for training \\
\hline
\end{tabular}

Table 16. Specific indicators of it capability maturity.

\begin{tabular}{lll}
\hline The basic ability of IT infrastructure & IT infrastructure service ability \\
& $\begin{array}{l}\text { The support ability of IT } \\
\text { infrastructure to the core business }\end{array}$ & Support capability to the asset management \\
$\begin{array}{c}\text { IT capability } \\
\text { maturity }\end{array}$ & Support capability to the production management \\
& The ability of IT infrastructure management & Support capability to the comprehensive management \\
& ST learning and innovation ability & IT learning and innovation ability \\
\hline
\end{tabular}

Table 17. Specific indicators of material.

\begin{tabular}{ll}
\hline Concentrated purchase index (material) \\
The completion rate of the materials tender \\
Inventory turnover rate \\
The idle rate of inventory \\
The power grid investment \\
Grid infrastructure investment \\
\hline
\end{tabular}

case of the statistics need. In the practical application of the index system for performance evaluation, the enterprise can use the AHP score method to diagnose the operation situation.

\section{References}

[1] Wang, J.-M. and Shi, T. (2012) Construction of Evaluation Index System for Smart Grid. North China Electric Power University, 40, 194-196.

[2] Song, Q. (2014) Research on Comprehensive Benefits Evaluation and System Planning of Smart Grid. Zhejiang University.

[3] Ding, D. and Qian, C.-Z. (2014) Security Stability Analysis of Photovoltaic Access to Regional Power Grid Based on P-V Curve. Computer Engineering \& Software, 37, 106-112.

[4] Yang, Q. and Chen, M.-Y. (2010) Research on Evaluation Index System of Provincial Electric Power Enterprise Based on AHP. Journal of Shaanxi University of Science \& Technology (Natural Science Edition), 28, 159-164.

[5] Cai, Z.-L. and Shu, H.-C. (2013) Research of Smart Grid IT Capability Maturity Model and Its Fuzzy Comprehensive Evaluation. Journal of Kunming University of Science and Technology (Natural Science Edition), 38, 68-73. 


\section{Submit or recommend next manuscript to SCIRP and we will provide best service for you:}

Accepting pre-submission inquiries through Email, Facebook, LinkedIn, Twitter, etc.

A wide selection of journals (inclusive of 9 subjects, more than 200 journals)

Providing 24-hour high-quality service

User-friendly online submission system

Fair and swift peer-review system

Efficient typesetting and proofreading procedure

Display of the result of downloads and visits, as well as the number of cited articles

Maximum dissemination of your research work

Submit your manuscript at: http://papersubmission.scirp.org/ 